\title{
Influencing Factors of Residents' Perception of Responsibilities for Heritage Conservation in World Heritage Buffer Zone: A Case Study of Libo Karst
}

\author{
Ruonan Fang ${ }^{1}{ }^{\circledR}$, Juan Zhang ${ }^{1,2}$, Kangning Xiong ${ }^{1, *}$, Kyung-Sik Woo ${ }^{3}$ and Ning Zhang ${ }^{1}$ \\ 1 School of Karst Science, State Engineering Technology Institute for Karst Desertification Control, Guizhou \\ Normal University, Guiyang 550001, China; fangrn611@163.com (R.F.); zhangjuanjoyce@163.com (J.Z.); \\ 15515263962@163.com (N.Z.) \\ 2 School of Management Science, Guizhou University of Finance and Economics, Guiyang 550025, China \\ 3 Department of Geology, College of Natural Science, Kangwon National University, Chuncheon 24341, Korea; \\ wooks@kangwon.ac.kr \\ * Correspondence: xiongkn@163.com
}

check for updates

Citation: Fang, R.; Zhang, J.; Xiong, K.; Woo, K.-S.; Zhang, N. Influencing Factors of Residents' Perception of Responsibilities for Heritage Conservation in World Heritage Buffer Zone: A Case Study of Libo Karst. Sustainability 2021, 13, 10233. https://doi.org/10.3390/ su131810233

Academic Editor: Brian Garrod

Received: 23 August 2021

Accepted: 7 September 2021

Published: 14 September 2021

Publisher's Note: MDPI stays neutral with regard to jurisdictional claims in published maps and institutional affiliations.

Copyright: (c) 2021 by the authors. Licensee MDPI, Basel, Switzerland. This article is an open access article distributed under the terms and conditions of the Creative Commons Attribution (CC BY) license (https:/ / creativecommons.org/licenses/by/ $4.0 /)$.

\begin{abstract}
Local residents of buffer zones, as a key factor in the World Heritage conservation and sustainable development, have not received sufficient attention in most developing countries, especially in the mountainous areas where poor and backward ethnic minorities live. To fill this research gap, this paper takes the Karst World Heritage buffer zone in Libo, Guizhou Province, southwest mountainous area of China, as the research area, and explores the factors that influence the perception of residents' responsibility for the World Heritage conservation by taking local residents who are involved in tourism management as the research subjects. Data were collected in the buffer zone of the Libo World Heritage site and 186 valid data were generated. SPSS 25.0 and AMOS 27.0 software were used to analyze the questionnaire data and construct a structural equation model. The results showed that environmental protection behavior had the greatest impact on residents' perception of responsibility for heritage conservation (0.93), followed by the recognition of heritage value (0.55), tourism positive impact (0.39), and place identification (0.34), among which the positive impact of tourism had a greater impact on the perception of heritage value (0.52). The results of the study emphasize the importance of the recognition of heritage value and positive tourism influence on the formation of residents' perception of responsibility for heritage conservation, and provide an empirical basis for the conservation of the World Natural Heritage.
\end{abstract}

Keywords: heritage conservation; perception of responsibility; residents; recognition of heritage value; the world heritage buffer zone

\section{Introduction}

World Heritage sites, with a unique value and global brand appeal, have gradually evolved into powerful tourist attractions and often become tourist hotspots. Tourism has been recognized as one of the major contributors to the economic development of countries and regions around the world [1], and their tourism development has become an unstoppable trend. With the continuous development of heritage tourism, which has brought many effects to the heritage sites, the responsibility of heritage conservation has attracted the attention of researchers from all walks of life, and a large number of studies have been conducted [2], mainly focusing on tourism enterprises, tourism developers, government departments, tourists, etc. Some scholars have noted that residents play an irreplaceable role in the protection of the environment and heritage, but few scholars have conducted in-depth studies on how to promote residents to consciously protect the heritage environment, especially the residents of the heritage buffer zone, and what are the factors affecting the protection of heritage. 
The heritage buffer zone is a designated area around the heritage site for the effective protection of the nominated heritage site. The buffer zone includes the area where the nominated heritage is directly located, important landscapes, and other areas or features that are functionally vital to the heritage and its protection, which can effectively avoid existing or be exposed to possible threats from outside the heritage boundary, thereby enhancing the integrity of the heritage. The sustainable development of the World Heritage sites depends on the good natural and cultural environment of the areas and buffer zone, and attention must be paid to the protection of the natural and cultural resources of the heritage sites and buffer zone. The existence of local residents as an "activation carrier" of heritage culture and a part of the social environment is an essential embodiment of the "authenticity" and "integrity" of the heritage and an important part of the heritage. The Libo World Heritage buffer zone has many villages; Fallon and Kriwoken (2003) believe that without the support and participation of community residents [3], the development of sustainable tourism is difficult. Therefore, the support of buffer zone residents is a vital factor for heritage site protection and tourism development.

The sense of responsibility mainly refers to a person's attitude towards the responsibilities, tasks, and missions that they undertake. As a kind of moral emotion, the perception of responsibility for heritage conservation is the unity of knowledge, feeling, and behavior, and an organic combination of human's inner spiritual value and external behavior norms. The perception of responsibility for heritage conservation refers to local residents' understanding and recognition of certain heritage conservation relations, importance and value of heritage conservation, as well as their cognition of heritage conservation actions. As a non-intellectual factor, the perception of responsibility is the catalyst for the transformation of responsibility cognition into responsibility behavior and plays a great regulating role in people's responsible behavior. Because of the universality and prominence of heritage value, heritage protection is everyone's responsibility, a collective responsibility [4]. It is generally believed that there is a high correlation between environmental awareness and environmental protection, that is, a strong awareness of environmental protection, or a perception of responsibility for environmental protection, leading to more environmental protection behaviors.

With the continuous development of heritage tourism, heritage faces more and more threats. Researchers have noted that the awareness and actions responsible for heritage sites can effectively support the sustainable development of World Heritage sites [5,6]. In recent years, more and more studies have focused on residents of tourist destinations $[7,8]$; local residents have more extensive contact with heritage sites than tourists, and their activities have a greater impact on the heritage site's environment $[9,10]$. For example, He et al., (2021) believed that the main reason for the cause of the karst landscape changes in the Guilin World Heritage site in China was human production activities [11]. The heritage buffer zone is an important area for heritage conservation, the attitude and behavior of residents towards heritage conservation determine the effectiveness of heritage conservation to a certain extent, but the current buffer zone residents and their perception of responsibility for heritage conservation have not received enough attention from researchers. Based on the existing literature and the analysis tools of SPSS 25.0 and AMOS 27.0, this paper aims to develop and test a comprehensive theoretical framework, which takes the perception of responsibility for heritage conservation as a predictor of the heritage conservation behavior of local residents who participate in the tourism operation in the heritage buffer zone. We explore the influence degree of heritage value cognition, place identification, positive impact of tourism, and environmental protection behavior on residents' perception of responsibility for heritage conservation, to find out the main influencing factors, objectively understand the development status of the study area, and put forward targeted development and protection suggestions, improve the level of its development and conservation, to provides a scientific reference for the conservation of the World Heritage site, and the improvement of the development benefit of the local residents in the buffer zone. 


\section{Study Area}

This study was carried out in the Libo Heritage Buffer Zone, a Karst World Heritage site in south China, which is located in Libo County, Qiannan Buyi, and Miao Autonomous Prefecture, Guizhou Province. It covers the Guizhou Maolan National Nature Reserve and Libo Zhangjiang National Scenic Spot, of which are Seven Small Holes and Seven Large Holes (Figure 1). The area of the heritage site is 29,518 hectares, with the central coordinates of $107^{\circ} 58^{\prime} 30^{\prime \prime} \mathrm{E}$ and $25^{\circ} 13^{\prime} 15^{\prime \prime} \mathrm{N}$. The buffer zone is 43,498 hectares.

There are minorities such as Shui, Buyi, Yao, Zhuang, and Miao in Libo Karst Heritage Site, whose population accounts for $84.20 \%$ of the total population and distributes concentrated adjacent to poor villages. The natural heritage site of Libo, which is dominated by karst landscapes, faces the inherent characteristics of the karst binary hydrogeological structure and the fragility of karst structure-function-habitat and heritage conservation are critical and urgent [12-14]. This has led to a strict control over the use of natural resources by local residents in the buffer zone of the heritage site, and the regional economic development has been affected to a certain extent with more significant contradictions.

The residents of the buffer zone rely on the heritage sites to develop tourism, most notably the residents of Gaoqiao Village, which is located in the ticket office of Libo Seven Small Holes and Seven Large Holes. They mainly rely on heritage tourism to develop their economy, and there are numerous tourist shops such as hotels, restaurants, shops, and tourist souvenirs. On the one hand, Gulei Village, Lapian Village, and Dongpeng Village rely on heritage tourism and, on the other hand, they rely on their own natural resources and ethnic cultural resources to develop tourism. Among them, Gaoqiao Village, Lapian Village, and Gulei Village are located near the Libo Seven Small Holes and Seven Large Holes Heritage Site and Dongpeng Village is situated near the Maolan National Nature Reserve.

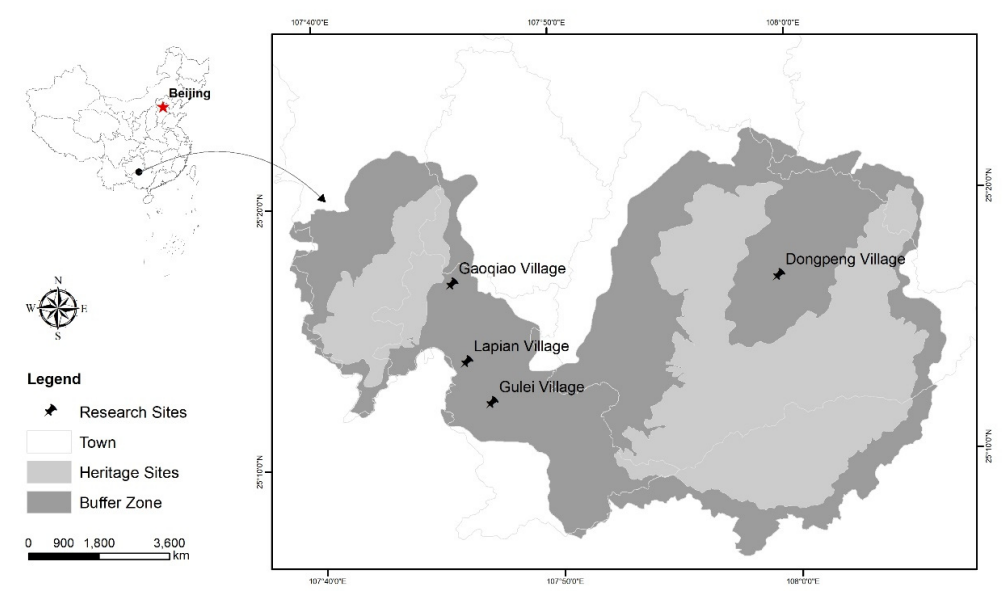

Figure 1. Location of the study area.

\section{Theoretical Basis}

\subsection{Cognition of Heritage Value}

Heritage value is one of the core topics of heritage discourse and practice. The World Natural Heritage pays more attention to the outstanding universal value, which has aesthetic value, scientific value, historical value, spiritual value, social value, etc. It has extraordinary natural phenomenon and remarkable aesthetic characteristics. Scholars in different fields have analyzed the value of the heritage system from several aspects [15], some scholars focus on economic, social, and cultural value [16], and some focus on the value of ecology, aesthetics, and geology, etc. [17]. The research is to evaluate the value of a particular aspect of heritage itself, lack of cognition, and understanding of heritage value based on human subjects. 
The value orientation of a certain thing will affect the attitude and behavior of the cognitive subject [18]. Shi et al., 2018 argued that environmental knowledge and environmental values are conducive to farmers' environmental protection behavior [19], so multiple cognition of a heritage value can promote residents' participation in heritage conservation [20], enhance residents' cognition of heritage value, and strengthen the responsibility consciousness of heritage protection [21]. However, the world heritage evaluation of participants was completed by authorities, experts, and the government [22], since experts, scholars, and government workers have more knowledge of heritage value, leading the public to believe that heritage value learning and understanding are their responsibility, which obviously makes heritage value perception and conservation not penetrate into the local residents. As a spatial carrier for the development of heritage tourism and heritage display, few scholars pay attention to the dissemination of heritage value among local residents, and the change of heritage value cognition impacts residents' attitude towards heritage and environmental behavior [23].

Based on the above analysis, the following hypothesis is proposed:

Hypothesis 1 (H1). Residents' perception of heritage value has a positive impact on environmental protection behavior.

\subsection{Place Identification}

A place is a particular area on the ground, a particular spot. Proshansky et al., (1983) believed that place identification develops through the interaction between individuals and the place [24]. On this basis, Moore and Graefe (1994) proposed that place identification is the identity substructure of people's cognition, attitude, and values towards a specific region or place and is the emotional attachment between people and a place [25]. It is the psychological identity generated by the combination of a place and an individual identity and image, which gives people a sense of local belonging [25,26], with more emphasis on the cognitive and affective components [27].

At present, domestic and foreign researchers on place identification pay more attention to the formation mechanism of place identification and explore several research variables such as demography characteristics from different research cases [28]. Some studies focus on tourists and explore the relationship between tourists' behavior, attitudes towards tourism, pro-environment behavior, and place identification. There is a lack of discussion on the relationship between local identification and the perception of responsibility for heritage conservation of local residents in the buffer zone of the World Heritage. Stedman (2002) found that residents with place identification living in the natural environment had a positive impact on their participation in environmental protection activities [29]. Local residents in the buffer zone have lived there for generations, so the local natural and cultural resources are more emotional. A higher place identification [30], which exists in people's unconscious, with internal, stable, and invisible characteristics, influences the behavior of individuals and groups, so as to promote the world heritage protection more enduring effect [31]. Environmental psychology and sociology have extensively studied the effect of place identification on behavior and found that these events explain one of the most important factors in people's support for environmental protection [32,33].

Based on the above analysis, the following hypothesis is proposed:

Hypothesis 2 (H2). Place identification has a positive impact on environmental protection behavior.

\subsection{Positive Impact of Tourism}

It has been a long time for the world heritage to develop tourism by using its unique value, and the positive impact of heritage tourism has been highlighted. The World Heritage Conservation Management Regulations compiled by the IUCN indicate that residents living in the heritage buffer zone should be able to participate in local activities [34]. Tourism development in heritage sites contributes to improving the economic development 
capacity and overall economic level of local residents [35], such as increasing family income, improving economic level, creating more job opportunities, etc. [36-39]. In addition, the development of heritage tourism has improved the local infrastructure environment, such as an improved public transport, increased shopping and leisure opportunities, improved infrastructure, etc. [36,39], improved the overall living environment of residents, and provided many conveniences. The development of heritage tourism provides local residents with the opportunity to contact the external environment and communicate with the outside world, promotes the change of values, moral concepts, family relations, lifestyle, etc., as well as the advancement of people's ideologies.

With the continuous development of heritage tourism, heritage sites have gradually realized the necessity and importance of undertaking and fulfilling social responsibilities [40]. In the rational use of the local natural and ecological environment, the tourism industry has created various benefits (especially economic earnings), effectively stimulating the surrounding communities to support tourism development and environmental protection, and affecting resident attitudes in support of environmental protection [41,42]. The buffer zone residents living in heritage sites stay around for a long time and use the natural resources and environment of the heritage as their livelihood choice for closer relations with the heritage site, under the condition of the economy and material benefits temptation, positive attention to environmental change and quality, as the perception of responsibility for heritage conservation is much more important for protecting the heritage site.

Based on the above analysis, the following hypothesis is proposed:

Hypothesis 3 (H3). Positive tourism impacts have positive impacts on environmental protection behaviors.

\subsection{Environmental Protection Behavior}

The relationship between heritage and human beings starts from the surrounding residents who have close contact with heritage sites [43], and as important stakeholders of heritage sites, residents' participation in heritage protection is crucial to the sustainable development of heritage sites [44]. In this paper, environmental protection behavior refers to various actions taken by residents of heritage buffer zones to coordinate the relationship with the heritage environment, protect the living environment and achieve a sustainable economic and social development of local residents. The main problems in the protection of World Heritage sites are the impact of the surrounding development and environmental pollution in the periphery, which threaten the natural heritage sites. Therefore, as the main activity groups around the heritage sites, the local resident should pay more attention to the protection of the heritage environment to promote the sustainable development of heritage sites.

China adheres to the government-led model of environmental protection, highlighting the responsibilities and actions of government departments in environmental protection, which lead to a low level of public participation and a serious tendency to self-avoid responsibility [44], which affects the improvement of environmental conditions. Environmental protection requires extensive and sustained public participation, especially the protection of World Heritage sites. Colchester (2004) stated that giving play to residents' right to participate in heritage protection is a "new paradigm" of environmental protection [45]. Residents' participation in environmental protection behaviors can be strengthened by stimulating residents' subject consciousness, self-value realization needs, and recognition of heritage value.

Based on the above analysis, the following assumption is proposed:

Hypothesis 4 (H4). Environmental protection behavior has a positive impact on the perception of responsibility for heritage conservation. 


\subsection{Perception of Responsibility for World Heritage Conservation}

First of all, action decisions recognize that residents realize the importance of heritage conservation in the process of participating in environmental protection; thus, deriving a perception of responsibility for heritage conservation. Secondly, recognition is the forerunner of action, only by correctly recognizing the value of heritage and having the awareness and responsibility of heritage conservation, will a protection act be promoted. In environmental psychology and sociology research, positive environmental protection attitudes increase the possibility of pro-environmental behavior [46]. The perception of responsibility for world heritage conservation is an attitude that spontaneously comes out in residents' daily business lives. The sense of responsibility of local residents in the buffer zone for heritage protection affects the development and management of heritage tourism, which is directly related to the sustainable utilization of World Heritage sites and the evolution of tourism development in the buffer zone and heritage environmental protection.

According to the Social Exchange Theory, the local residents in the heritage buffer zone, as "economical people", will decide their future behaviors according to the interaction results with the outside world and bear the final results of the development of heritage tourism. The exchange is based on benefits and costs and can only be realized when both parties perceive that they benefit more from the exchange than they give up. Therefore, to obtain more benefits from the development of heritage tourism, residents may take environmentally responsible actions to protect the natural environment of the heritage site [47], which in turn contributes to the sustainable development of tourism in the destination. Under the guidance of Social Exchange Theory, we can identify effective measures on how to promote tourism benefits as well as heritage conservation promotion to positively influence and inhibit negative impacts on heritage conservation, to promote the sense of responsibility of residents in the buffer zone for heritage conservation.

In Organizational Behavior Studies, it has been confirmed that personal satisfaction is an important driving factor affecting their behaviors [48], and that residents of heritage buffer zones are more concerned about changes in the heritage environment when they are satisfied with the current economic development of tourism and their lives. He et al., (2018) showed that residents' satisfaction could affect residents' environmental responsibility behavior [49]; therefore, the purpose of this study was to verify the measurement of major factors that affect residents' perception of responsibility for heritage conservation in the buffer zone, and check the degree of influence of each factor. Amos 27.0 was used for the analysis, and the structural equation model and research hypothesis are shown in Figure 2.

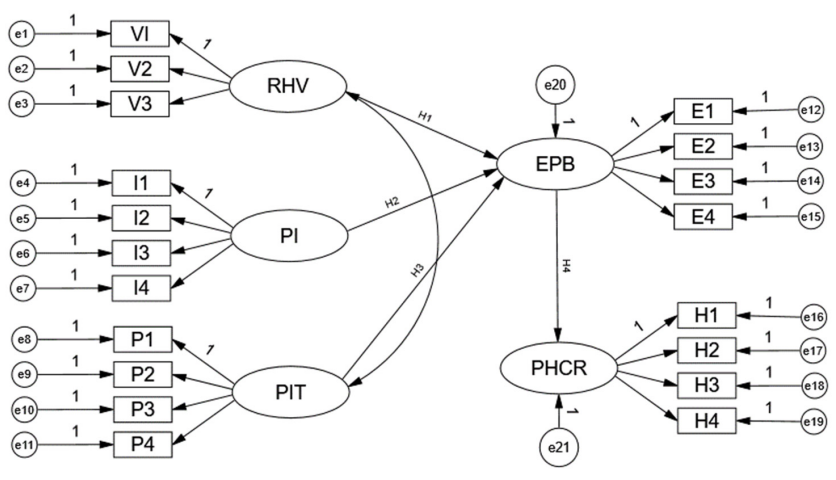

Figure 2. Theoretical model and hypotheses.

\section{Empirical Research}

\subsection{Data Source}

Due to many factors such as transportation, tourism infrastructure, and distribution of heritage resources, only some villages were involved in the heritage tourism development, so this paper selected four villages with a deeper involvement in tourism development as the research sites, took local residents involved in tourism operations as the target 
population, and adopted a random sampling method to conduct the survey. The questionnaire was conducted by seven doctoral and master students in geography who had received training in questionnaire research methods. The groups conducted door-to-door surveys in the streets of villages participating in the heritage tourism development, first asking if they were local residents and if they were willing to participate. After receiving a positive response, the researcher provided a description of the questionnaire and asked the respondents. Participation in the study was voluntary, and participants were not asked to provide their names and contact information to protect their privacy. The survey was conducted from 11 to 17 May 2021, and 201 questionnaires were sent out, excluding incomplete and invalid questionnaires, and 186 valid questionnaires were obtained, with a response rate of $92.54 \%$. This questionnaire adopted the five-point Likert scale ( 1 = strongly opposed; 2 = oppose; $3=$ in general; $4=$ agree; $5=$ strongly agree) to evaluate these measurement items.

\subsection{Sample Analysis}

SPSS 25.0 was used for a descriptive statistical analysis of the data. The demographic data of the respondents are shown in Table 1; among the surveyed villages, Gaoqiao Village had the largest number of respondents with a total of 131 , accounting for $70.4 \%$ of the sample, followed by Lapian Village with 42 , accounting for $22.6 \%$, which was related to the distance from the heritage site. Among the male and female proportions in the sample, women (55.4\%) accounted for more than men (44.6\%), men were more likely to go out for work, while women were more likely to choose local employment because they have to take care of children and the elderly. Most of the respondents were young and middle-aged people, with the highest proportion in the 36-60 age group (47.8\%). More than $50 \%$ of the respondents only had a junior high school degree or below $(57 \%)$, and only $0.5 \%$ had a bachelor's degree or above, which shows that residents generally have a low level of education. The proportion of employees engaged in tourism was the highest $(23.7 \%)$, and the proportion of self-employment was $64.4 \%$, including (catering, hotel, stall, and supermarket) operators; the enthusiasm of local residents to participate in tourism management was higher. In the tourism income, there were at least 17 people $(9.1 \%)$ with incomes below CNY 10,000, and 57 people (30.6\%) with incomes between 30,000 and CNY 50,000, one-third of the tourism employees had low incomes; 43 people $(23.1 \%)$ had an income of CNY 50,000-100,000, and 25 people (13.4\%) had an income of more than CNY 100,000; some tourism employees had a considerable income. 
Table 1. Statistical analysis of the frequency of demographic variables.

\begin{tabular}{|c|c|c|c|c|c|c|c|}
\hline Characteristics & Characteristic Distribution & Frequency & $\begin{array}{c}\text { Percentage } \\
(\%)\end{array}$ & Characteristics & Characteristic Distribution & Frequency & $\begin{array}{l}\text { Percentage } \\
(\%)\end{array}$ \\
\hline \multirow{3}{*}{ Gender } & Man & 83 & $44.6 \%$ & & Not uneducated & 29 & $15.6 \%$ \\
\hline & Women & 103 & $55.4 \%$ & & Junior high school and below & 106 & $57 \%$ \\
\hline & Lapian Village & 42 & $22.6 \%$ & & Junior College and Undergraduate & 25 & $13.4 \%$ \\
\hline \multirow[t]{3}{*}{ Village } & Gulei Village & 8 & $4.3 \%$ & & Bachelor or above & 1 & $0.5 \%$ \\
\hline & Dongpeng Village & 5 & $2.7 \%$ & & Agritainment & 15 & $8.1 \%$ \\
\hline & $18-35$ & 84 & $45.2 \%$ & & Catering & 38 & $20.4 \%$ \\
\hline \multirow{2}{*}{ Age } & 60 and above & 13 & $7 \%$ & Type of tourism & Stall & 32 & $17.2 \%$ \\
\hline & Less than CNY 10,000 & 17 & $9.1 \%$ & & Supermarket & 17 & $9.1 \%$ \\
\hline \multirow{4}{*}{$\begin{array}{l}\text { Average annual } \\
\text { income }\end{array}$} & CNY 10,000-20,000 & 44 & $23.7 \%$ & & Staff (scenic spot/hotel/catering) & 44 & $23.7 \%$ \\
\hline & CNY 30,000-50,000 & 57 & $30.6 \%$ & & Rest & 7 & $3.8 \%$ \\
\hline & CNY 50,000-100,000 & 43 & $23.1 \%$ & & & & \\
\hline & More than 100,000 & 25 & $13.4 \%$ & & & & \\
\hline
\end{tabular}




\subsection{Measurement Model}

In this paper, except for basic demographic information, other variables were all latent variables, which needed to be evaluated before testing the structural equation model [50]. This research, at the core of the latent variables and measured variables, related model research in tourism development and environmental protection on the basis of the combination of the World Heritage Buffer on the residents' perception of development and protection of heritage. It operated 19 observed variables which were equipped with heritage value cognition, place identification, positive impact of tourism, environmental protection behavior and the perception of responsibility for heritage conservation six-core latent variables, three observation indicators were set for the core latent variables of heritage value, and the other four corresponding observation variables were set, respectively. The specific design of observation indicators is shown in Table 2.

Table 2. Indicator system of buffer zone residents' perception of responsibility for heritage conservation model.

\begin{tabular}{|c|c|c|}
\hline Latent Variable & Observational Variable & Variable Name \\
\hline \multirow[b]{3}{*}{$\begin{array}{l}\text { Recognition of heritage value } \\
\text { (RHV) }\end{array}$} & Do you know that Libo is the World Natural Heritage site? & V1 \\
\hline & Do you understand the value of the Libo World Heritage site? & $\mathrm{V} 2$ \\
\hline & $\begin{array}{l}\text { Do you think landmarks and explanations on the road or within the } \\
\text { heritage site can help you understand the value of the heritage? }\end{array}$ & V3 \\
\hline \multirow{4}{*}{ Place identification (PI) } & Here, people help each other & I1 \\
\hline & I am proud of the local national culture & $\mathrm{I} 2$ \\
\hline & $\begin{array}{c}\text { I think the village where I live is more cultural and more suitable } \\
\text { for living }\end{array}$ & I3 \\
\hline & Satisfied with your current lifestyle & I4 \\
\hline \multirow{4}{*}{$\begin{array}{l}\text { Environmental protection } \\
\text { behavior } \\
(\mathrm{EPB})\end{array}$} & $\begin{array}{l}\text { After the successful application, I am more willing to devote myself to } \\
\text { local environmental protection }\end{array}$ & E1 \\
\hline & $\begin{array}{l}\text { The sight of tourists digging up vegetation or capturing wildlife } \\
\text { will deter }\end{array}$ & E2 \\
\hline & $\begin{array}{c}\text { You know or are involved in special heritage preservation organizations } \\
\text { and groups }\end{array}$ & E3 \\
\hline & You approve of environmental education or environmental publicity & $\mathrm{E} 4$ \\
\hline \multirow{4}{*}{$\begin{array}{l}\text { Positive impact of tourism } \\
\text { (PIT) }\end{array}$} & Tourism development has improved the local infrastructure & P1 \\
\hline & The development of tourism has promoted the status of women & $\mathrm{P} 2$ \\
\hline & The development of tourism has greatly expanded the local economy & P3 \\
\hline & $\begin{array}{l}\text { The development of tourism increases the opportunities for } \\
\text { making money }\end{array}$ & $\mathrm{P} 4$ \\
\hline \multirow{4}{*}{$\begin{array}{c}\text { Perception of heritage } \\
\text { conservation responsibility } \\
\text { (PHCR) }\end{array}$} & $\begin{array}{l}\text { I would feel guilty if the revenue from tourism comes at the cost of } \\
\text { damaging the environment }\end{array}$ & $\mathrm{H} 1$ \\
\hline & $\begin{array}{c}\text { Realizing that tourism revenues can only grow if we preserve } \\
\text { our heritage }\end{array}$ & $\mathrm{H} 2$ \\
\hline & Be willing to pay for heritage conservation if tourism revenue increases & $\mathrm{H} 3$ \\
\hline & $\begin{array}{l}\text { I want my children to return to my hometown to participate in heritage } \\
\text { conservation and tourism development }\end{array}$ & $\mathrm{H} 4$ \\
\hline
\end{tabular}

\subsection{Data Reliability Analysis and Exploratory Factor Analysis}

The validity and reliability analysis of the questionnaire and related variables were conducted based on the survey data, and this questionnaire was conducted by SPSS 25 version. Cronbach's Alpha reliability coefficient $\alpha \geq 0.90$ means very good, $0.80 \leq \alpha \leq 0.90$ means good, $0.70 \leq \alpha<0.80$ means fair, $0.60 \leq \alpha<0.70$ indicates that it is acceptable, and coefficient $\alpha<0.60$ indicates unacceptable. It can be seen from Table 3 that the reliability coefficients of the five latent variables were all greater than 0.6, indicating good internal consistency. The $\mathrm{KMO}$ test ranged from 0 to 1 , and $\mathrm{KMO}>0.9$ is very suitable for a factor analysis, $0.8<\mathrm{KMO}<0.9$ suitable, above 0.7 is ok, 0.6 is a little bad, and less than 0.5 is not suitable for a factor analysis. The KMO values of PI, PIT, and PHCR were slightly lower 
than 0.7 , and the KMO values of other latent variables were greater than 0.7 , indicating that the potential variables were suitable for a factor analysis among themselves.

Table 3. Reliability analysis and validity test of latent variable.

\begin{tabular}{ccc}
\hline Latent Variable & Cronbach's Alpha & KMO \\
\hline RHV & 0.886 & 0.747 \\
PI & 0.631 & 0.643 \\
EPB & 0.713 & 0.745 \\
PIT & 0.747 & 0.670 \\
PHCR & 0.633 & 0.661 \\
\hline
\end{tabular}

As shown in Table 4, the reliability of 19 observation variables in the model established in this study was 0.898 , which had a high internal consistency and high reliability. In this study, the results of the KMO test were 0.882 , Sig. $<0.05$ ( $p$ value $<0.005$ ), which rejected the null hypothesis, so the questionnaire had a good validity.

Table 4. Questionnaire validity, KMO, and Bartlett test.

\begin{tabular}{|c|c|c|c|c|}
\hline Number & Cronbach's Alpha & & KMO and Bartlett Tests & \\
\hline \multirow{2}{*}{19} & $\begin{array}{c}\text { Cronbach Alpha } \\
\text { based on } \\
\text { standardized terms }\end{array}$ & \multicolumn{2}{|c|}{$\begin{array}{l}\text { Number of KMO sampling } \\
\text { suitability variables }\end{array}$} & 0.882 \\
\hline & $\begin{array}{c}0.888 \\
\text { Cronbach Alpha } \\
0.888\end{array}$ & $\begin{array}{c}\text { Bartlett's } \\
\text { sphericity test }\end{array}$ & $\begin{array}{c}\text { Approximate chi-square } \\
\text { DOF } \\
\text { prominence }\end{array}$ & $\begin{array}{c}1479.631 \\
171 \\
0.000\end{array}$ \\
\hline
\end{tabular}

\section{Empirical Analysis of Model}

\subsection{Model Fitting Verification}

According to the test results of the model fit in Table 5, the results of NFI, IFI, CFI, and GFI were all greater than 0.9 , and PGFI $>0.5$, indicating that the results were acceptable; the value of CMIN/DF ranged from one to three, indicating rigor. The calculated value in this paper was 2.477, which was within the acceptable range. The value of RMSEA was less than 0.08 , indicating that it was acceptable. In this study, the value of RMSEA was 0.069 , less than 0.08 . So, it was judged that the structural model was stable and the causal relationship discussed existed. Therefore, from the whole, the fitting of the model of the structural equation in this paper was better, and the model could be studied and analyzed.

Table 5. Test results of model fit degree.

\begin{tabular}{cccccccc}
\hline Test Index & CMIN/DF & PGFI & NFI & IFI & CFI & GFI & RMSEA \\
\hline Fitting index & 2.477 & 0.656 & 0.923 & 0.914 & 0.921 & 0.927 & 0.069 \\
$\begin{array}{c}\text { Range } \\
\text { Reference range }\end{array}$ & $1-5$ & $>0.5$ & $>0.9$ & $>0.9$ & $>0.9$ & $>0.9$ & $<0.08$ \\
\hline
\end{tabular}

\subsection{Structural Model Hypothesis Verification Evaluation and Result Analysis}

The data of each observation variable were imported into Amos27 software for calculation, and the structural equation model analysis results can be obtained in Table 6 and Figure 3. The recognition of heritage value (RHV) had a significant positive impact on environmental protection behavior $(p<0.001)$, and the impact effect was the largest. For every unit increase in the recognition of heritage value, environmental protection behavior increased by 0.554 units; therefore, the $\mathrm{H} 1$ hypothesis was valid. The recognition of heritage value was the basic requirement of participating in heritage environmental protection, only by understanding the outstanding universal value of World Heritage and recognizing the non-renewability and scarcity of such a value could residents realize the 
importance of protecting the heritage environment. In recognition of heritage value, the "V3 Do you think landmarks and explanations on the road or within the heritage site can help you understand the value of the heritage?" and "V2 Do you understand the value of Libo World Heritage site?" influence degree was large, and the numerical number was 0.91 , 0.85 , respectively. The "V1 Do you know that Libo is the World Natural Heritage site?" impact was relatively small, with a number of 0.8 . It was suggested that more attention should be paid to popularizing the knowledge of the Libo World Heritage value among the buffer zone residents, and the design of interpretation boards in the buffer zone and the heritage site to promote the residents to have a better understanding of the heritage site.

Table 6. Estimated results of structural relationship model.

\begin{tabular}{ccccccccc}
\hline & & & Unstd. & Std. & S.E. & C.R. & P & Result \\
\hline EPB & $<-$ & RHV & 0.214 & 0.554 & 0.041 & 5.156 & $* * *$ & Support H1 \\
EPB & $<-$ & PI & 0.371 & 0.342 & 0.100 & 3.715 & $* * *$ & Support H2 \\
EPB & $<-$ & PIT & 0.514 & 0.391 & 0.137 & 3.744 & $* * *$ & Support H3 \\
PHCR & $<-$ & EPB & 0.813 & 0.930 & 0.173 & 4.686 & $* * *$ & Support H4 \\
\hline Note: ${ }^{* * *}$ means significant at $<0.001$ level. & & & & &
\end{tabular}

The positive impact of tourism (PIT) was second and had a significant positive effect on environmental protection behavior $(p<0.001)$. If the positive impact of tourism increased by 1 unit, the environmental protection behavior would increase by 0.39 units; therefore, hypothesis $\mathrm{H} 2$ was valid. The positive impact of tourism was not only reflected in the economic aspect, but also reflected in the change of the social and living environment. Among them, the impact of the economy was more significant, "P3 The development of tourism has greatly expanded the local economy" and "P4 The development of tourism increases the opportunities for making money" had the largest positive impact on tourism, with numbers of 0.88 and 0.78 , respectively. Second was that the living environment (P1 Tourism development has improved the local infrastructure) had a large impact, with a number of 0.5 , and the social environment (P2 The development of tourism has promoted the status of women) had a small impact at 0.41 .

Place identification (PI) was also one of the important factors affecting the environmental protection behavior of residents in the buffer zone, and had a significant positive impact on the environmental protection behavior $(p<0.001)$. For every 1 unit increase in place identification, environmental protection behavior increased by 0.34 units; therefore, hypothesis $\mathrm{H} 3$ was valid. Minority nationalities accounted for the majority in the Libo World Heritage buffer zone. Miao, Buyi, Yao, and other minorities with their own languages and cultures, due to the language differences and ideological restrictions, "I2 I am proud of the local national culture" had the greatest influence on place identification, with a number of 0.71 . The "I4 Satisfied with your current lifestyle" influence was next, at 0.61. "I1 Here, people help each other" and "I3 I think the village where I live is more cultural and more suitable for living" had relatively little impact at 0.57 and 0.35 . 


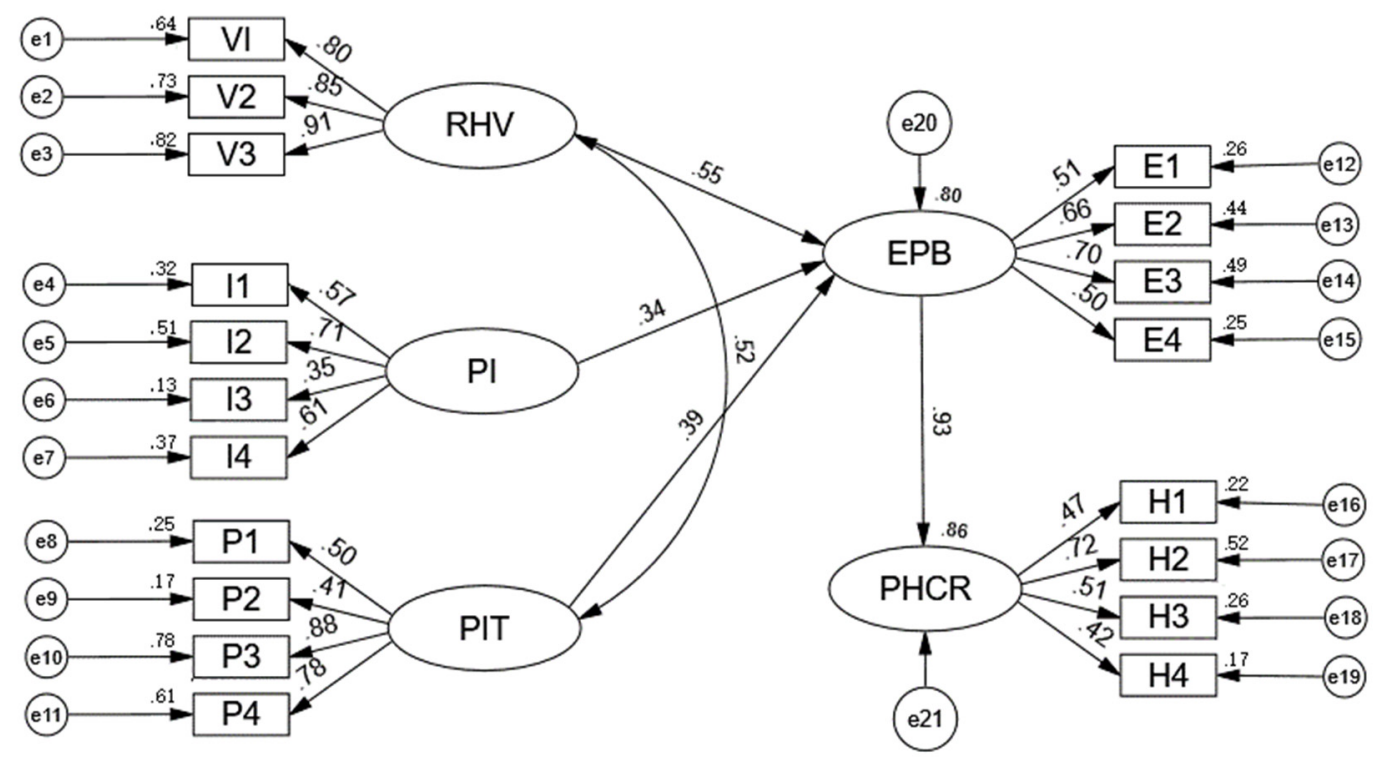

Figure 3. The model results of residents' perception of responsibility for heritage conservation in the buffer zone.

Environmental protection behavior (EPB) had a significant positive impact on the perception of responsibility for heritage conservation $(p<0.001)$, and the impact effect was the largest. For every 1 unit increase in environmental protection behavior, the perception of responsibility for heritage conservation would increase by 0.93 units; therefore, $\mathrm{H} 4$ hypothesis was valid. Residents' perception of responsibility for heritage conservation was formed in the practice of participating in environmental protection; among them, "E2 The sight of tourists digging up vegetation or capturing wildlife will deter" and "E3 You know or are involved in special heritage preservation organizations and groups" had a greater impact, with numbers of 0.66 and 0.7 , respectively, indicating that residents' environmental protection behaviors were most influenced by environmental protection publicity, education, understanding or participation in heritage protection organizations and groups. "E1 After the successful application, I am more willing to devote myself to local environmental protection" came second, with a number of 0.51. "E4 You approve of environmental education or publicity" had a small impact at 0.5 . Local ethnic minorities generally had a low level of education, as $72.6 \%$ of the respondents were from junior middle school or below, and their ability to receive books, internet, TV, and other information was low. Therefore, residents' participation in environmental protection actions mainly came from the publicity, education, and supervision of government departments.

Among the latent variables of $\mathrm{PHCR}$, "H2 Realizing that tourism revenues can only grow if we preserve our heritage" and "H3 Be willing to pay for heritage conservation if tourism revenue increases" had a large impact, and the numbers were 0.72 and 0.51 , respectively. "H1 I would feel guilty if the revenue from tourism comes at the cost of damaging the environment" was the second at 0.47. "H4 I want my children to return to my hometown to participate in heritage conservation and tourism development" had a small impact at 0.42 . The above analysis shows that the local residents' perception of responsibility for heritage conservation in the buffer zone was closely related to their own tourism income.

\section{Discussion and Conclusions}

This study focused on residents in the heritage buffer zone who participate in tourism operations, explored the main factors influencing the heritage protection responsibility awareness, as well as the influence degree of various factors. The results showed that the recognition of heritage value, place identification, environmental protection, and tourism behavior's positive impact had an impact on heritage conservation responsibility aware- 
ness, the heritage, and tourism value cognition of the influence degree of the positive effect was the largest. Place identification, the positive impact of tourism, and cognition of the heritage value in previous studies showed that they have a promoting effect on environmental protection; this study differed in that it began with resident's participation in environmental protection initiatives, which led to the perception of responsibility for heritage conservation, and then promoted residents' adoption of heritage conservation behaviors. Taking into account the overall education level and receptiveness of local residents, the attention and protection of the overall living environment were gradually transferred to the formation of heritage awareness and a sense of responsibility for protection.

In general, the recognition of heritage value plays a crucial role in residents' perception of responsibility for heritage conservation. This article found that the heritage value cognition affects the residents' attitude towards conservation. Residents who realize the outstanding universal value of heritage have reverence for heritage and are more active in conservation. The impact of heritage value perception on conservation was consistent with the results of previous studies, that is, the more awareness, the more likely it is to promote the conservation and sustainable development of heritage. The recognition of value is the starting point for the conservation and development of the World Natural Heritage. In the Charter of Bula, it was emphasized that understanding the importance of heritage, that is, the "value of existence" [51], is the core of all activated utilization. The Libo World Heritage site is located in the economically backward and minority communities in the mountainous areas of Southwest China [52]. Compared with other natural heritage sites, residents in the buffer zone have more isolated information and have a lower degree of education popularization. Residents of heritage value, heritage resources, and heritage function are poorly understood, so the heritage protection consciousness is not strong. Government departments should take local heritage conservation as a starting point, and adopt heritage education methods (e.g., basic education, secondary school education, public education, etc.) and technical means to enhance the dissemination and popularization of heritage knowledge [53-55], raise awareness of heritage conservation, and increase the sense of responsibility among residents.

Tourism had a positive impact on residents' perception of responsibility for heritage conservation. The development of tourism has made local residents aware of the importance of World Heritage sites and promoted their awareness of the environment and heritage protection. However, for the vast majority of residents of heritage areas in developing countries, poverty is a real issue [56,57], and heritage conservation is not. Studies by Ross and Wall (1999) and Stone and Nyaupane (2014) show that residents' attitudes and behaviors towards local resources and environment are mainly influenced by livelihood [56,58], but few studies currently focus on local residents' perception of heritage conservation responsibility in the context of heritage tourism. "Utilization" of heritage sites has become a new expression of heritage conservation and a new topic to conform to the sustainable development of heritage. Libo buffer zone residents rely on heritage resources to develop the economy; therefore, it is of great significance for heritage conservation to start with the buffer zone residents to improve tourism development benefits and promote their perception of responsibility for heritage conservation. Local residents' perception of responsibility for heritage conservation will help to limit or avoid damage to the heritage environment in the tourism operation or development and give some benefits for environmental protection. This finding was consistent with the research results of Davis et al., (2011) and Lee and Moscardo (2005) [59,60].

Environmental protection behavior directly affects the formation of perception of responsibility for heritage conservation. In the process of environmental protection, residents can deepen their understanding of the environment in the places where they live and work. Libo local government stipulated a series of environmental protection measures, such as no littering anywhere, no cutting, no catching wild animals, centralized waste, and sewage disposal, which residents complied with. The buffer zone residents are close to the heritage site, and the environmental conditions of the heritage site are closely related to the daily 
behaviors of residents, which requires the extensive and continuous participation of residents, especially the implementation of their own environmental protection responsibility into daily life practice. In order to improve the environment of heritage sites, in addition to adopting scientific and technological management methods, local residents should change their existing environmental damage behaviors and cultivate a perception of responsible heritage protection.

Place identification can promote residents' sense of responsibility for heritage conservation. The emotional connection between residents and heritage sites exists objectively, which can influence individual heritage conservation behaviors. If such emotion is properly guided and played, the enthusiasm of the public can be fully mobilized to participate in the protection. Studies have proved that residents' place identification can be expressed through nature protection or protection behaviors [61]. Residents of Libo heritage buffer zone have lived there for generations, and they have deep feelings for the place where they live. In order to create themselves a better living environment, they should pay attention to the changes in the environment in daily production and life.

\section{Impacts and Limitations}

\subsection{Significance}

The theoretical contribution of this paper was to establish a structural equation model to explain the formation of the residents' perception of heritage conservation responsibility. The model showed the different pathways that the influence of residents' perceptions of responsibility for heritage conservation through which sustainability of heritage conservation and development can be promoted. In recent years, there have been numerous studies on heritage protection, but few empirical studies have involved the heritage buffer zone, especially heritage tourism operators, which are closely related to heritage conservation. As a matter of fact, residents in buffer zones live around the heritage sites for a long time and make use of local natural resources and the environment for their livelihood, which is more closely related to heritage protection. Therefore, it is more important for the natural ecological security of the heritage sites to take responsible heritage conservation actions, local residents who participate in heritage tourism operators should have more environmental sensitivity, and the perception of responsibility for heritage conservation than those who do not participate in tourism development because their economic interests are closely related to the environmental condition of the heritage site. The results of this study provide empirical evidence for the conservation and management of heritage sites. Only by paying attention to the development of residents in heritage buffer zones and improving the enthusiasm of local residents for heritage conservation can the protection and sustainable development capacity of heritage sites be improved.

Heritage tourism is a form of tourism that is based on the enjoyment of natural resources, so natural heritage tourism should pay more attention to the protection of the ecological environment. For a long time, tourism has been regarded as an important industry to promote economic development, especially in developing countries, underdeveloped areas, and mountainous areas inhabited by ethnic minorities, which have a strong dependence on tourism. Economically underdeveloped areas always have beautiful natural environments and scenery, and the positive impact of tourism development in this area on local residents is particularly significant. Economic conditions have a significant impact on residents' perception of responsibility for heritage conservation; therefore, local governments should pay more attention to the income of local residents participating in tourism development, improve the overall income level of residents, and enhance the residents' perception of responsibility for heritage conservation.

On the one hand, there is not enough professional reflection and promotion on recognizing the heritage value in China's heritage protection. On the other hand, the way and paradigm of value recognition are single [62], and the Libo World Heritage is also facing the same problem in protection. Therefore, the local government departments should actively play a leading role in spreading the heritage value in a way that is popular with the local 
people, so that more residents can know what is the world heritage, what is the value of the world heritage, and why we should actively protect the world heritage.

\subsection{Research Limitations and Future Research Directions}

The perception of responsibility for the heritage conservation model in this study had the following limitations: First of all, because of the large area of the buffer zone, the distance between the village and heritage site, the planning and development of heritage tourism and the fact that villages still participate in tourism development in the core area, only a few buffer zone villages participate in the heritage tourism operation, resulting in a small number of questionnaires and incomplete coverage. Secondly, there may be other influencing factors for the residents' perception of responsibility for heritage conservation, which can be further explored in future studies. In addition, the study was conducted mainly in the Libo World Heritage buffer zone, which may only be suitable for economically underdeveloped and poorly educated areas in the mountainous areas of Southwest China. Future studies can be compared with residents of other karst World Heritage buffer zones to explore the main factors affecting heritage protection. In future studies, multiple cases and transnational cases can be selected for comparison to compare heritage tourism destinations with different levels of economic development [26], in order to find out the impact of the heritage tourism economy on residents' perception of heritage conservation responsibility.

Author Contributions: R.F.: Methodology, Software, Validation, Formal analysis, Investigation, Data curation, Writing—original draft. J.Z.: Writing—review and editing, Supervision. K.X.: Investigation, Project administration, Funding acquisition. N.Z.: Software, Data curation. K.-S.W.: Validation. All authors have read and agreed to the published version of the manuscript.

Funding: This research was funded by the World Top Discipline Program of Guizhou Province (No. 1252019 Qianjiao Keyan Fa), and the Key Project of Science and Technology Program of Guizhou Province (No. 54112017 Qiankehe Pingtai Rencai), and the China Overseas Expertise Introduction Program for Discipline Innovation (No. D17016), and the Postgraduate Education Innovation Program Project of Guizhou Province (No. Qianjiaohe YJSCXJH [2020] 112).

Institutional Review Board Statement: The study was conducted according to the guidelines of the Declaration of Helsinki, and approved by the School of Karst Science, Guizhou Normal University.

Informed Consent Statement: Informed consent was obtained from all subjects involved in the study. Written informed consent has been obtained from the participants to publish this paper.

Data Availability Statement: The data presented in this study are available on request from the corresponding author.

Conflicts of Interest: The authors declare that they have no known competing financial interests or personal relationships that could have appeared to influence the work reported in this paper.

\section{References}

1. Girard, L.F.; Nijkamp, P. Cultural Tourism and Sustainable Local Development; Ashgate Publishing: London, UK, 2009.

2. Zhang, C.Z. Heritage responsibility: Conception, characteristics and research issues. Tour. Trib. 2014, $29,45-51$.

3. Fallon, L.D.; Kriwoken, L.K. Community involvement in tourism infrastructure-The case of the Strahan Visitor Centre, Tasmania. Tour. Manag. 2003, 24, 289-308. [CrossRef]

4. Li, Y.Q.; Wang, X.Z.; Chen, P. Development and testing of heritage responsibility scale: Based on perspectives of tourists and residents. Tour. Trib. 2019, 34, 60-75.

5. Su, L.; Swanson, S.R.; He, X. A scale to measure residents perceptions of destination social responsibility. J. Sustain. Tour. 2019, 28, 873-897. [CrossRef]

6. Su, L.; Huang, S.S.; Pearce, J. How does destination social responsibility contribute to environmentally responsible behavior? A destination resident perspective. J. Bus. Res. 2018, 86, 179-189. [CrossRef]

7. Jaafar, M.; Noor, S.M.; Rasoolimanesh, S.M. Perception of young local residents toward sustainable conservation programmes: A case study of the Lenggong World Cultural Heritage Site. Tour. Manag. 2015, 48, 154-163. [CrossRef] 
8. Gursoy, D.; Boğan, E.; Dedeoğlu, B.B.; Çalışkan, C. Residents' perceptions of hotels' corporate social responsibility initiatives and its impact on residents' sentiments to community and support for additional tourism development. J. Hosp. Tour. Manag. 2019, 39, 117-128. [CrossRef]

9. Cheng, T.M.; Wu, H.C. How do environmental knowledge, environmental sensitivity, and place attachment affect environmentally responsible behavior? An integrated approach for sustainable island tourism. J. Sustain. Tour. 2015, 23, 557-576. [CrossRef]

10. Su, L.; Swanson, S.R. The effect of destination social responsibility on tourist environmentally responsible behavior: Compared analysis of first-time and repeat tourists. Tour. Manag. 2017, 60, 308-321. [CrossRef]

11. He, G.; Zhao, X.; Yu, M. Exploring the multiple disturbances of karst landscape in Guilin World Heritage Site, China. Catena 2021, 203, 105349. [CrossRef]

12. Yang, M.D. On the fragility of karst environment. Yunnan Geogr. Environ. Res. 1990, 2, 21-29.

13. Ford, D.C.; Williams, P.W. Karst Hydrogeology and Geomorphology; Wiley: New Jersey, NJ, USA, 2007; pp. 471-472.

14. Xiong, K.N.; Chi, Y.K. The problems in southern China karst ecosystem in southern of China and its countermeasures. Ecol. Econ. 2015, 31, 23-30.

15. Zhang, Y. Comprehensive evaluation of the value of "Luxiang ancient village" as a settlement agricultural cultural heritage. South. Agric. 2015, 30, 5-9.

16. He, H.Z. Connotation, protection and utilization of technical agricultural cultural heritage. J. Agric. Archaeol. $2016,4,323-328$.

17. Xie, N.G. On the protection and utilization of natural and cultural heritage in scenic areas. Tour. Trib. 2002, 17, 8-9.

18. Yang, Z.X. On value orientation evaluation and value cognition evaluation. J. Tianjin Norm. Univ. Soc. Sci. Ed. 2000, 26, 1-6.

19. Shi, Z.H.; Jin, R.R.; Mu, H.J.; Qin, L.S. Research on farmers' pro-environment behavior from the perspective of media education: The mediating effects of environmental knowledge and values. Arid Land Resour. Environ. 2018, 32, 76-81.

20. Wang, L. Impacts of tourism on traditional rural landscape: A case study of ancient ginkgo biloba conservation in Haiyang Township, Guilin. Guangxi Soc. Sci. 2013, 38, 28-31.

21. Zhang, C.Z.; Zeng, L.P.; Lin, H.X. Community residents' perception of corporate social responsibility in scenic spot development: Based on the perspective of place attachment. Hum. Geogr. 2015, 30, 136-142.

22. Ni, S.S.; Li, M.X.; Li, J.Y.; Jin, D.W.; Liang, Y.Q. Recognition and evaluation of world heritage value in China: A case study of The World Natural Heritage Danxia Mountain in Guangdong province. J. Tour. Forum 2013, 6, 39-44.

23. Zhang, C.Z.; You, W. Heritage declaration and community residents' recognition of heritage value: From the perspective of social representation: A case study of Kaiping Diaolou and village. Tour. Trib. 2009, 24, 43-47.

24. Proshansky, H.M.; Fabian, A.K.; Kaminoff, R. Place-identity: Physical world socialization of the self. J. Environ. Psychol. 1983, 3 , 57-83. [CrossRef]

25. Moore, R.L.; Graefe, A.R. Attachments to recreation settings: The case of rail-trail users. Leis. Sci. 1994, 16, 17-31. [CrossRef]

26. Zhou, L.Q.; Li, Q.C.; Zhu, L. Behavioral performance, human emotion and tourist environment responsible for behavioral intention: An improved model based on the theory of planned behavior. J. Zhejiang Univ. Humanit. Soc. Sci. 2014, 44, 88-98.

27. Coyle, A.; Murtagh, N. Identity Process Theory; Cambridge University Press: London, UK, 2014.

28. Qiu, P.; Zhang, P. Place identity and world heritage conservation intention: A case study of Hangzhou section of Beijing-Hangzhou Grand Canal. J. Cap. Norm. Univ. Nat. Sci. 2020, 41, 41-51.

29. Stedman, R.C. Toward a social psychology of place: Predicting behavior from place-based cognitions, attitude, and identity. Environ. Behav. 2002, 34, 561-581. [CrossRef]

30. Rollero, C.; Piccoli, N.D. Place attachment, identification and environment perception: An empirical study. J. Environ. Psychol. 2010, 30, 198-205. [CrossRef]

31. Lei, Q.Y. Cultural identity and public law protection of intangible cultural heritage. J. Minzu Univ. China Philos. Soc. Sci. Ed. 2013, 40, 97-103.

32. Fielding, K.; McDonald, R.; Louis, W. Theory of planned behaviour, identity and intentions to engage in environmental activism. J. Environ. Psychol. 2008, 28, 318-326. [CrossRef]

33. Gatersleben, B.; Murtagh, N.; Abrahamse, W. Values, identity and pro-environmental behaviour. Contemp. Soc. Sci. 2014, 9 , 374-392. [CrossRef]

34. Srijuntrapun, P.; Fisher, D.; Rennie, H.G. Assessing the sustainability of tourism-related livelihoods in an urban world heritage site. J. Heritage Tour. 2017, 13, 395-410. [CrossRef]

35. Jaafar, M.; Rasoolimanesh, S.M.; Lonik, K.A.T. Tourism growth and entrepreneurship: Empirical analysis of development of rural highlands. Tour. Manag. Perspect. 2015, 14, 17-24. [CrossRef]

36. Andereck, K.L.; Valentine, K.M.; Knopf, R.C.; Vogt, C.A. Residents' perceptions of community tourism impacts. Ann. Tour. Res. 2005, 32, 1056-1076. [CrossRef]

37. Choi, H.C.; Sirakaya, E. Sustainability indicators for managing community tourism. Tour. Manag. 2006, 27, 1274-1289. [CrossRef]

38. Lee, T.H.; Jan, F.H. Can community-based tourism contribute to sustainable development? Evidence from residents' perceptions of the sustainability. Tour. Manag. 2019, 70, 368-380. [CrossRef]

39. Woosnam, K.M.; Norman, W.C.; Ying, T. Exploring the theoretical framework of emotional solidarity between residents and tourists. J. Travel Res. 2009, 48, 245-258. [CrossRef]

40. Ngo, T.; Lohmann, G.; Hales, R. Collaborative marketing for the sustainable development of community-based tourism enterprises: Voices from the field. J. Sustain. Tour. 2018, 26, 1325-1343. [CrossRef] 
41. Campbell, S.J.; Kartawijaya, T.; Yulianto, I.; Prasetia, R.; Clifton, J. Co-management approaches and incentives improve management effectiveness in the Karimunjawa National Park, Indonesia. Mar. Policy 2013, 41, 72-79. [CrossRef]

42. Fan, J.F.; Wang, C.Y.; Guo, J.T.; Li, W.J. Driving forces of heritage tourism destination social responsibility. Econ. Issues 2019, 11, 120-128.

43. Wager, J. Developing a strategy for the Angkor World Heritage Site. Tour. Manag. 1995, 16, 515-523. [CrossRef]

44. Yang, Q.; Tian, Y.H.; Tong, Y.L. The mechanism of community participation in promoting the development and protection of world Natural Heritage Site: The case of Hunan Langshan. Econ. Geogr. 2020, 40, 233-240.

45. Colchester, M. Conservation policy and indigenous peoples. Environ. Sci. Policy 2004, 7, 145-153. [CrossRef]

46. Milfont, T.L.; Duckitt, J. The environmental attitudes inventory: A valid and reliable measure to assess the structure of environmental attitudes. J. Environ. Psychol. 2010, 30, 80-94. [CrossRef]

47. Lee, T.H. Influence analysis of community resident support for sustainable tourism development. Tour. Manag. 2013, 34, 37-46. [CrossRef]

48. Chan, S.H.J.; Lai, H.Y.I. Understanding the link between communication satisfaction, perceived justice and organizational citizenship behavior. J. Bus. Res. 2017, 70, 214-223. [CrossRef]

49. He, X.H.; Hu, D.B.; Su, L.J. Residents' perception of fairness, relationship quality and environmental responsibility behavior in tourist destinations. J. Tour. 2018, 33, 117-131.

50. Anderson, J.C.; Gerbing, D.W. Structural equation modeling practice: A review and recommended two-step approach. Psychol. Bulletion 1988, 103, 411-423. [CrossRef]

51. Darvill, T. Value systems and the archaeological resource. Int. J. Herit. Stud. 1994, 1, 52-64. [CrossRef]

52. Xiong, K.N.; Li, G.C.; Wang, L.Y. Conservation and sustainable development of libo World Natural Heritage Site in Karst region, south China. Chin. Landsc. Archit. 2012, 28, 66-71.

53. Castro-Calviño, L.; Rodríguez-Medina, J.; Gómez-Carrasco, C.J.; López-Facal, R. Patrimonializarte: A heritage education program based on new technologies and local heritage. Educ. Sci. 2020, 10, 176. [CrossRef]

54. Gizzi, F.T.; Biscione, M.; Danese, M.; Maggio, A.; Pecci, A.; Sileo, M.; Potenza, M.R.; Masini, N.; Ruggeri, A.; Mercurio, F.; et al. Students meet cultural heritage: An experience within the framework of the Italian school-work alternation (SWA)—From outcomes to outlooks. Heritage 2019, 2, 1986-2016. [CrossRef]

55. Azman, N.; Halim, S.A.; Liu, O.P.; Saidin, S.; Komoo, I. Public education in heritage conservation for geopark community. Procedia Soc. Behav. Sci. 2010, 7, 504-511. [CrossRef]

56. Ross, S.; Wall, G. Evaluating ecotourism: The case of North Sulawesi, Indonesia. Tour. Manag. 1999, 20, 673-682. [CrossRef]

57. Snyman, S. The role of tourism employment in poverty reduction and community perceptions of conservation and tourism in southern Africa. J. Sustain. Tour. 2012, 20, 395-416. [CrossRef]

58. Stone, M.T.; Nyaupane, G.P. Rethinking community in community-based natural resource management. Community Dev. 2014, 45, 17-31. [CrossRef]

59. Eder, R.; Arnberger, A. The influence of place attachment and experience use history on perceived depreciative visitor behavior and crowding in an Urban National Park. Environ. Manag. 2012, 50, 566-580. [CrossRef]

60. Lee, W.H.; Moscardo, G. Understanding the impact of ecotourism resort experiencing on tourists' environmental attitudes and behavioural intentions. J. Sustain. Tour. 2005, 13, 546-565. [CrossRef]

61. Davis, J.L.; Le, B.; Coy, A. Building a model of commitment to the natural environment to predict ecological behavior and willingness to sacrifice. J. Environ. Psychol. 2011, 31, 257-265. [CrossRef]

62. $\mathrm{Wu}, \mathrm{S}$. Research and reference on the strategies of urban and rural heritage protection and management based on value cognition: A case of the world heritage site of Angkor monument. Urban Archit. 2021, 18, 113-117. 